\title{
AGUSTÍN COSOVSCHI
}

\section{Doing Science in Futureless Times. War, Political Engagement, and National Mission in Croatian Ethnology during the 1990s}

\begin{abstract}
From a perspective rooted in intellectual and cultural history, the author accounts for the profound disciplinary transformations undergone by ethnology as practised at the Institute of Ethnology and Folklore Research (IEF) in Zagreb, Croatia, during the early 1990s. In a context shaped by the Yugoslav breakup and the outbreak of war, and also as a result of theoretical transformations that had taken place in Croatian ethnology during the previous decade, many researchers at this institute undertook a new ethnological practice that involved among other things the questioning of the notion of objectivity and the redefinition of the political role of the ethnologist. The author analyses these changes in terms of converging factors, namely the theoretical influences coming from American, French, and German scholarship, the disciplinary crisis caused by a self-perception of social marginality, and the radical and violent sociopolitical transformations of the early 1990s.
\end{abstract}

Agustín Cosovschi is an Associate Researcher at the Centre d'Études Turques, Ottomanes, Balkaniques et Centrasiatiques $(\mathrm{CETOBaC})$ in Paris and currently works as a DAADpostdoctoral fellow at the Historical Institute of the Humboldt University in Berlin.

The early 1990s were turbulent times in Croatia. The former Yugoslav republic went through a period of turmoil, with deep consequences that have lasted to this day, not only as a result of the demise of the communist regime and the dissolution of the Yugoslav federation, but also as a result of the war that prolonged itself until 1995, leaving thousands of military and civil victims, massive destruction, and deep scars in the collective memory of society. If these developments left long-lasting marks in Croatian political, economic, social, and cultural life, they also had deep effects on scholarly activity, heavily transforming the conditions of production of scientific knowledge. ${ }^{1}$

${ }^{1}$ This article is based on Agustín Cosovschi, Penser la crise dans la périphérie. Les sciences sociales en Serbie et en Croatie durant la dissolution de la Yougoslavie, PhD thesis, École des Hautes Études en Sciences Sociales (EHESS), Paris, and the University of San Martín, Buenos Aires, 2018. 
During the 1990s, Croatian social sciences faced multiple challenges. Among other things, researchers had to deal with the interruption of academic cooperation with colleagues in Serbia and Montenegro, regular financial problems, and recurrent meddling in the academic world on the part of the Croatian government, led by the 'Croatian Democratic Union' (Hrvatska demokratska zajednica, HDZ). Moreover, the context of war persuaded many in Croatia of the need to defend their country from what they perceived as an alien occupation, thus reinforcing ideological uniformity and casting a shadow of suspicion on critical intellectuals. At the same time, ideological and theoretical transformations dating back to the 1970s and 1980s, the weakening of Marxist thought, and the arrival of new theoretical influences such as structuralism, feminism, and postmodernism, had opened up a space for social sciences to rethink their research agendas and conceptual repertoires.

In this context, Croatian ethnology offers a fascinating case of theoretical and methodological renovation. Already since the 1970s, many Croatian ethnologists had become acquainted with Western anthropological production, which had triggered important theoretical and methodological changes in the discipline. However, a long tradition of self-censorship and ideological neutrality practised during most of the socialist period had also produced a self-perception of social marginality. In such a context, the military assault of the Jugoslovenska narodna armija (Yugoslav People's Army, JNA) in 1991 and the ensuing violence against the civil population drove many ethnologists, and in particular a number of researchers working at the Institute for Ethnology and Folklore Research (Institut za etnologiju i folkloristiku, IEF), to actively engage politically and to reconceptualize their ethnological work in ways that involved questioning the notion of objectivity and, precisely, redefining the political role of the ethnologist.

This article accounts for these profound disciplinary transformations. It traces how Croatian researchers faced the new situation, the effects of this time of turmoil and violence on Croatian ethnology, and how it paved the way for the rise of a new and politically engaged ethnology. The members of the Institute for Ethnology and Folklore Research are in the focus of my exploration. First, I trace the history of Croatian ethnology before 1990, its dominant intellectual traditions, and in particular its theoretical transformations since the 1970s. Second, I examine how, in the early 1990s, the new political and social context in Croatia transformed the social sciences as a whole, and ethnology in particular. I analyse how the outbreak of war drove a number of ethnologists at the IEF towards a stronger political engagement, thus breaking with their long tradition of political abstinence. In the last section, I analyse in detail an eminent product of the IEF's work of the time, the book Fear, 
Death, and Resistance. An Ethnography of War. Croatia, 1991-1992, edited by Lada Čale Feldman, Ines Prica, and Reana Senjković in 1993.

In my research, I draw from the journals Etnološka tribina and Narodna umjetnost during the period from 1991 to 1995 and a series of other articles, unpublished works, books as well as materials from statistical and institutional archives from these years and beyond. In addition, the article builds on more than twenty in-depth interviews with ethnologists, sociologists, and political scientists from Zagreb carried out in 2016 and 2017. In the following, the personal names of my interviewees will not be revealed. When quoting a particular extract, my interlocutors will be referred to by their profession and number, as well as the place and the date of the interview.

The majority of my interviewees were professional academics during the 1990s. However, I included also some younger researchers in order to incorporate a different generational perspective. The interviews were conducted in order to gather information about the personal experiences of Croatian researchers, but without any methodological pretension beyond subjectivity. With full awareness of the problems inherent to memory and hindsight in personal accounts, the testimonies were collected with the goal of providing evidence about the past that could not be retrieved from any written sources, in order to shed light, at least partially, on the subjective dimension of this particular intellectual transformation. ${ }^{2}$

\section{From National Science to Theoretical Modernization}

The origins of ethnology in Croatia are to be found in the $19^{\text {th }}$ century, in an intellectual context influenced by romanticist, nationalist, and populist thought. Conceived as a 'national science', ethnology was seen as an instrument at the service of national identity creation and state building. As elsewhere in Europe, it primarily devoted itself to the collection of popular and peasant customs, mores, and traditions that were supposed to represent the core of the national ethos. However, its gaze was turned inward in a more comprehensive way than among anthropologists in the Western world, where it had emerged to a great extent as a result of the colonial experience with its discovery of the 'Other'. American anthropologist Joel Halpern noticed:

'In the English-speaking world, it was the folk and peasant who were foreigners, since rural-urban sub-cultural variations on native soil, as distinct from class differences, had begun to decline markedly by the eighteenth century. This was particularly true in those parts of the British Isles least affected by the impact of industrialization, such as Ireland. But in the Slavic-speaking lands in general and Yugoslavia in particular these terms continued to refer to the embodiment of the

${ }^{2}$ Lynn Abrams, Oral History Theory, Abingdon, New York/NY 2010, 78-106. 
nation. The study of man has for Yugoslav scholars meant the study of their own way of life, an intellectual justification for their independent political existence rather than a world-view correlated with that imperial sense of destiny, implicit or explicit, which has characterized Western European and American anthropology. ${ }^{3}$

In the study of these local ways of life, many ethnologists in Yugoslavia developed a characterological discourse that aimed to determine the essential traits of the South Slavs, as in the case of the prominent geographer Jovan Cvijić, ${ }^{4}$ sometimes even arguing for the existence of a particular 'Slavic spirituality', as in the case of Vladimir Dvorniković. ${ }^{5}$ For the development of Croatian ethnology in particular, the influence of Antun Radić would be essential. The author of a foundational work, the Osnova za sabiranje $i$ proučavanje građe o narodnom životu (The basis of collecting and studying materials of folk life) from 1897, Radić was also an active character in national political life together with his brother Stjepan, being one of the founders of the Croatian Peasants' Party (Hrvatska seljačka stranka, HSS), a party that not only favoured Croatian national emancipation in the lands of the Austro-Hungarian empire, but that would also struggle for the autonomy of the Croatian nation in the context of interwar Yugoslavia. ${ }^{6}$ In 1924, the first chair of ethnology was established in the Faculty of Arts at the University of Zagreb and soon fell under the direction of Milovan Gavazzi. Along with his disciple Branimir Bratanić, Gavazzi would be the guardian of Croatian ethnology during the decades to come: first during the monarchic period, afterwards under the authoritarian and collaborationist regime of Ante Pavelić during the Second World War, and later during the communist era, developing a historical-genetic approach to ethnological research that would become an unavoidable reference for Croatian ethnologists of all future generations. ${ }^{7}$

\footnotetext{
${ }^{3}$ Joel Halpern, Observations on the Intellectual History of Ethnology and Other Social Sciences in Yugoslavia, Comparative Studies in Society and History 11, no. 1 (1969), 17-26, 18, DOI: 10.1017/S0010417500005120. All internet references were accessed on 4 February 2019.

${ }^{4}$ Jovan Cvijić, La peninsule balkanique, Paris 1918.

${ }^{5}$ Vladimir Dvorniković, Karakterologija Jugoslovena, Belgrade 2000. For a brief analysis of the meaning of Dvorniković's work in context, see Vladimir Dvorniković, Epic Man, in: Diana Mishkova/Marius Turda/Balazs Trencsenyi, eds, Anti-Modernism. Radical Revisions of Collective Identity. Discourses of Collective Identity in Central and Southeast Europe 1770-1945, vol. 4, Budapest 2014, 212-218.

${ }^{6}$ Ivo Banac, The National Question in Yugoslavia. Origins, History, Politics, Ithaca/NY 1984; Dejan Djokić, Elusive Compromise. A History of Interwar Yugoslavia, London 2007.

7 Milovan Gavazzi, Kulturna analiza etnografije Hrvata, Narodna starina 8 (1928); Milovan Gavazzi, Pregled etnografije Hrvata, Zagreb 1940; Milovan Gavazzi, Sudbina stare slavenske baštine kod južnih Slavena, Belgrade 1959.
} 
The first years of socialist Yugoslavia would push ethnology towards a fairly marginal position. Accused of being a bourgeois science, suspected of nationalism due to its history and its devotion to a social character such as the peasant, which the official ideology of the Yugoslav state considered backwards and reactionary, the development of the discipline faced several obstacles. Following the Soviet model, ethnology would officially become 'ethnography', a transformation that expressed itself for instance in the establishment of the Ethnographic Institute (Etnografski institut) at the Academy of Sciences and Arts (Akademija nauka i umetnosti) in Zagreb in 1947. Moreover, the acceptance of deterministic and linear notions of historical development that derived from vulgar interpretations of Marxist thought would often hamper the advancement of more sophisticated methods and theories for ethnological research such as functionalism, and would incidentally also obstruct a richer dialogue between Marxist thought and ethnology. ${ }^{8}$ Furthermore, the Yugoslav state would encourage the development of a parallel discipline, folkloristics, responsible for regulating the expression of national symbols in public events such as folklore festivals. Thus, in a context characterized by the Yugoslav state's repeated interventions in the field and by a general suspicion towards everything that reeked of being nationally oriented, many ethnologists would end up assuming a position of political silence, fostering an attitude of extreme professionalism and ideological detachment. ${ }^{9}$

In Croatia, both Gavazzi and Bratanić encouraged a strong depoliticization in the discipline, which manifested primarily through the abandonment of certain subjects of research considered to be dangerous, such as religious life. This allowed for a certain ideological autonomy in the field, which among other things manifested in the minor influence of Marxist thought, contrary to what happened in neighbouring disciplines such as political science and sociology where Marxist intellectuals had a deep influence at institutions such as the Faculty of Political Science, the Faculty of Arts, or the Institute for Social Research at the University of Zagreb. ${ }^{10}$ But the depoliticization encouraged by

${ }^{8}$ Gordana Gorunović, Pseudomarksizam i protofunkcionalizam u srpskoj etnologiji: Kulišić vs. Filipović, Etnoantropološki problemi 1, no. 2 (2006), 185-208. Although Gorunović refers in her article to Serbian ethnology, Spiro Kulišić's Montenegrin origin and Milenko Filipović's Bosnian background, among other things, suggest that the issues discussed in the article concern the wider Yugoslav ethnological community, well beyond strictly Serbian borders.

9 Slobodan Naumović, Identity Creator in Identity Crisis. Reflections on the Politics of Serbian Ethnology, Anthropological Journal on European Cultures 8, no. 2 (1999), 39-128, www. jstor.org/stable/43234857; Jasna Čapo / Valentina Gulin Zrnić, Un siècle d'ethnologie croate. Une réflexion critique, Ethnologie française 43 (2013), 189-193.

${ }_{10}$ Mirjana Kasapović, ed, Izlazak iz množine? Stanje hrvatske političke znanosti, Zagreb 2007; Radule Knežević / Slaven Ravlić, eds, Hrvatska politologija 1962-2002, Zagreb 2002. For the case of sociology, see Marija Bodganović, ed, Sociologija u Jugoslaviji. Institucionalni 
Gavazzi and Bratanić would also reinforce the growing political marginality of ethnologists in the public sphere, with long-term consequences on the development of the discipline. ${ }^{11}$

Nevertheless, from the 1970s onwards ethnology would go through a process of significant theoretical and conceptual modernization in Zagreb, Belgrade, and Ljubljana. This process, which some authors have called 'the anthropologization of Yugoslav ethnology', was encouraged to a great extent by the influences of Western anthropological production, through contact with foreign researchers and thanks to active politics of translation that made developments in linguistics, structuralism, and cultural anthropology accessible to Yugoslav readers. ${ }^{12}$ It would also be the result of the arrival of a new generation of researchers to the field, among others Dunja Rihtman-Auguštin in Croatia and Ivan Kovačević and Dušan Bandić in Serbia. Under the influence of anthropologists such as the Polish-British Bronislaw Malinowski, ${ }^{13}$ the French Claude Lévi-Strauss, ${ }^{14}$ and the American Margaret Mead, ${ }^{15}$ and later by authors such as the German Hermann Bausinger, the American Clifford Geertz, and the Norwegian Fredrik Barth, these scholars gave a new interpretative twist to ethnology, finally driving it out of its protracted theoretical freeze.

In Croatia this process had its indisputable centre at the Institute for Ethnology and Folklore Research, originally established in 1948 as the Institute for Folk Art (Institut za narodnu umjetnost), in Zagreb. From the 1970s onwards, researchers at the IEF began developing an ethnological practice that moved away from the traditional approaches fostered by Gavazzi and Bratanić at the university. Under the leadership of intellectuals such as Dunja RihtmanAuguštin, researchers at the IEF would no longer conceive culture as a mere grouping of fixed mores and customs destined to be the object of ethnological collection, but rather as a complex network of permanently produced and reinvented elements that the ethnologist had to interpret in their social context. Moreover, the research interests of ethnologists would shift, from the

razvoj, Belgrade 1990; Antun Petak, Osnivanje i razvoj Instituta za društvena istraživanja Sveučilišta u Zagrebu (1964-1993), in: Vlasta Ilišin, ed, Institut za društvena istraživanja u Zagrebu 1964-2014, Zagreb 2014, 12-59.

${ }^{11}$ Dunja Rihtman-Auguštin, Ethnology, Myth and Politics. Anthropologizing Croatian Ethnology, Farnham 2004, 50.

${ }^{12}$ Rihtman-Auguštin, Ethnology, Myth and Politics; Čapo / Zrnić, Un siècle d'ethnologie croate, 192-194; Ivan Kovačević, Istorija srpske antropologije, Belgrade 2015, 18-21.

${ }_{13}$ Bronislav Malinovski, Naučna teorija kulture, Belgrade 1970 (English orig. Bronislaw Malinowski, A Scientific Theory of Culture, and Other Essays, Chapel Hill 1944).

${ }^{14}$ Claude Lévi-Strauss, Tužni tropi, Zagreb 1960 (French orig. Tristes Tropiques, Paris 1955).

${ }^{15}$ Margaret Mead, Spol i temperament u tri primitivna društva, Zagreb 1968 (English orig. Sex and Temperament in Three Primitive Societies, New York/NY 1935). 
study of cultural artefacts as the expression of immutable traditions to the investigation of contemporary culture under socialism, turning now to the analysis of new subjects such as everyday life, the phenomenon of folklorism, and popular religious life. ${ }^{16}$ As a result, between the 1970 s and the 1990s Croatian ethnology became internally split along two major fronts, one remaining more traditionally ethnological and the other becoming closer to cultural anthropology, a historical phase of the discipline that Ivan Lozica has called a 'two-headed ethnology'. ${ }^{17}$

The 1980s witnessed a number of important developments in that regard, with researchers at the IEF producing new theoretical reflections that pushed forward the borders of traditional ethnology. Drawing from the works of Hermann Bausinger and Ingeborg Weber-Kellermann, for instance, Dunja Rihtman-Auguštin developed a new approach to the concept of 'custom' (običaj), conceiving it no longer as an immutable historical object, but rather as a text that should be interpreted dynamically in a changing social context. ${ }^{18}$ Moreover, Olga Supek deconstructed the concept of 'ethnos', drawing from the influence of American and British cultural anthropology, but also from the works of Fredrik Barth and from authors such as Immanuel Wallerstein. She analysed the construction of ethnic identity as no longer a primordial and fixed identity, but rather as a result of cultural and political relations taking place at the local and global levels in the contemporary world. ${ }^{19}$

At the same time, ethnologists were beginning to develop an increasingly active political conscience. After the crushing of the Croatian Spring in 1971, Yugoslavia witnessed a period characterized by, among other things, the reinforcement of censorship and a stronger grip on public debate by the League of Communists. ${ }^{20}$ The intellectual world would be a privileged stage for this renewed control on public speech, with such notorious episodes as the trial against jurist Mihailo Đurić ${ }^{21}$ and the dismissal of members of the Praxis group from Belgrade university in $1974 .^{22}$ This was also true in Croatia, where the League of Communists' militant attitude towards dissident intellectuals

\footnotetext{
${ }^{16}$ Dunja Rihtman-Auguštin, Etnologija naše svakodnevnice, Zagreb 1988; Dunja RihtmanAuguštin / Maja Povrzanović, eds, Folklore and Historical Process, Zagreb 1989.

17 Ivan Lozica, Tekstom o terenu, in: Jasna Čapo Žmegač / Valentina Gulin Zrnić / Goran Pavel Šantek, eds, Etnologija bliskoga. Poetika i politika suvremenih terenskih istraživanja, Zagreb 2006, 237-260.

${ }^{18}$ Dunja Rihtman-Auguštin, Njemački pojmovi 'Sitte und Brauch' i poimanje običaja u našoj etnologiji, Narodna umjetnost 24, no. 1 (1987), 83-92.

${ }_{19}$ Olga Supek, Etnos i kultura, Migracijske i etničke teme 5, no. 2-3 (1989), 145-153.

${ }^{20}$ Radina Vučetić, Monopol na istinu, Belgrade 2016, 330-374.

${ }^{21}$ Nick Miller, The Nonconformists. Culture, Politics, and Nationalism in a Serbian Intellectual Circle, 1944-1991, Budapest 2007, 194-206.

${ }^{22}$ Gerson S. Sher, Praxis. Marxist Criticism and Dissent in Socialist Yugoslavia, Bloomington 1977, 227-239.
} 
gave place to episodes of ideological control. ${ }^{23}$ Such changes in the Yugoslav political landscape opened the space for dissent in the public space. By the end of the 1980s, some researchers at the IEF formulated strong criticism against the tradition of political neutrality that had been developed during the previous decades, under Gavazzi and Bratanić.

A clear articulation of this critical spirit is detectable in the works of Lydia Sklevicky. Trained at the Faculty of Arts of the University of Zagreb, where she studied sociology and ethnology, Sklevicky in 1984 defended her Master's thesis entitled 'Women and Power', a critical examination of the role of women in the struggle for national liberation and the historical experience of the Antifascist Women's Front (Antifašistički front žena). ${ }^{24}$ In the following years, her research had wide repercussions in the fields of social history and anthropology, indicating the deep gaps that existed between official narratives and historical facts with respect to the role of women in politics. ${ }^{25}$ Being part of the second-wave feminist generation that Zsófia Lóránd has called 'new Yugoslav feminism', ${ }^{26}$ Sklevicky participated in the creation of the study group 'Woman and Society' (Žena i društvo) at the Croatian Sociological Association (Hrvatsko sociološko društvo) in 1979. She was also engaged in such initiatives as the creation of the first telephone line to assist victims of domestic violence in Zagreb in 1988.

Sklevicky died young as a result of a car accident on 21 January $1990 .{ }^{27}$ Her early death, however, would not keep her from leaving a legacy of politically engaged research that would influence many, especially among her colleagues at the IEF. Among her most influential texts, the text 'Profession of an Ethnologist', published posthumously in 1991, expressed strong criticism against the decades of political neutrality fostered during the socialist period. Drawing from a survey conducted among the members of the Croatian Ethnological Society (Hrvatsko etnološko društvo), she stressed that an overwhelming

${ }^{23}$ Dejan Jović, Jugoslavija. Država koja je odumrla, Zagreb 2003, 345-351.

${ }^{24}$ Lydia Sklevicky, Žene i moć. Povjesna geneza jednog interesa, Master Thesis, University of Zagreb, 1984.

${ }^{25}$ Lydia Sklevicky, More Horses than Women. On the Difficulties of Founding Women's History in Yugoslavia, Gender \& History 1, no. 1 (1989), 68-75, DOI: 10.1111/j.1468-0424.1989. tb00235.x.

${ }^{26}$ In contrast to the pre-Second World War feminist history of the country, this denomination refers to the network of militant and intellectual groups that emerged in Yugoslavia during the 1970s and developed a feminist critique of the Yugoslav state through numerous cultural, academic and political activities that persisted into the 1980s. Cf. Zsófia Lóránd, Socialist-Era New Yugoslav Feminism between 'Mainstreaming' and 'Disengagement'. The Possibilities for Resistance, Critical Opposition and Dissent, The Hungarian Historical Review 5, no. 4 (2016), 854-881.

${ }^{27}$ Francisca De Haan / Krassimira Daskalova / Anna Loufti, eds, A Biographical Dictionary of Women's Movements and Feminisms. Central, Eastern, and South Eastern Europe, 19th and 20th Centuries, Budapest 2006, 516-520. 
majority of ethnologists sensed that their discipline was socially marginal, also with respect to other social sciences. ${ }^{28}$ According to Sklevicky, the marginal position of ethnology could be attributed in part to its ideological inconvenience during the socialist period. However, she also reproached ethnologists for not raising their voices and not having interceded in favor of the autonomy of the profession, in favor of professional arbitrage in social matters, for not expressing themselves concerning the need for democratizing society, for the respect of human liberties and rights and other similar issues'.29 Although she maintained that she did not advocate the politicization of the discipline, she claimed:

'We can of course ask ourselves if this distance with respect to politics is useful for the development of the discipline. However, I have the impression that the positive aspects [...] are much less than the negative ones, such as losing a genuine connection to social processes, suppressing our voice from public discourse and renouncing to become responsible for the well-being and the development of the whole social system. ${ }^{30}$

Croatian ethnology thus went through a profound process of change. After decades of stagnation, the discipline gradually turned from being a scholarly pursuit devoted to highbrow debates to being a lively, scholarly inquiry into the transformations of contemporary society. Ethnology was in the midst of a deep transformation when the Yugoslav crisis broke out, rapidly introducing war and uncertainty to the life of Croatian citizens, scholars among them.

\section{The Thin Walls of the Ivory Tower. Croatian Social Sciences in Face of War}

\section{The Consequences of Disaster}

In 1990, after over forty years of communist rule and a decade of economic, political, and social crisis, multiparty elections were held in Yugoslavia at the level of the republics. Voters favoured the rise of nationalist forces in all republics, and Croatia was no exception, witnessing the victory of the conservative Croatian Democratic Union (HDZ) over the reformed Communist Party. In a context of mounting tension between Yugoslav republics and growing political uncertainty, the new Croatian president, the nationalist and anticommunist historian Franjo Tuđman, began pushing for an agenda of national independence that soon met the resistance of the Serbian and Montenegrin

\footnotetext{
${ }^{28}$ Lydia Sklevicky, Profesija etnolog. Analiza pokazatelja statusa profesije, 1991, in: Dunja Rihtman-Auguštin, ed, Konji, žene, ratovi, Zagreb 1996, 190, 202.

${ }_{29}$ Sklevicky, Profesija etnolog, 195-196.

${ }^{30}$ Sklevicky, Profesija etnolog, 196.
} 
leaderships and the Yugoslav People's Army (JNA). It also created growing tensions with the Serb community of Croatia, which then made up about $12 \%$ of the total population of the republic, and began to lean politically towards Jovan Rašković's Serbian Democratic Party (Srpska demokratska stranka, SDS), a party that put forward an agenda of cultural and, eventually, even territorial autonomy for the Serbs in Croatia. ${ }^{31}$

After more than a year of negotiations at the federal level, rising social discontent, escalating armed conflict between Croatian security forces and Croatian Serbs, as well as growing concern over the involvement of the army in the political process, in June 1991 the republics of Croatia and Slovenia declared their independence. This decision triggered the immediate reaction of the JNA, an institution that saw its raison d'être in the defence of Yugoslav territorial integrity. In July 1991, it launched operations in Croatia, rapidly seizing a third of the Croatian territories, in coalition with local Serb forces. Thus, a war was initiated against Croatian military and paramilitary forces that would last until 1995, causing massive destruction and leaving thousands of civilian and military casualties, as well as dozens of thousands of refugees. ${ }^{32}$ Military conflict spread to the neighbouring republic of Bosnia and Herzegovina, too, with dramatic consequences throughout the region. ${ }^{33}$

The early 1990s thus were a turbulent period in the history of Croatia, in which war, economic crisis, rising authoritarianism, and mounting nationalism combined into what historian Dušan Bilandžić described unequivocally as a civilizational decline. ${ }^{34}$ The latter had deep consequences also on the realm of the social sciences, as I show in what follows. I conducted personal interviews with ethnologists, sociologists, and political scientists, among others,

${ }^{31}$ Lenard J. Cohen, Broken Bonds. Yugoslavia's Disintegration and Balkan Politics in Transition, Colorado 1993; Dejan Jović, The Slovenian-Croatian Confederal Proposal. A Tactical Move or an Ultimate Solution?, in: Jasna Dragović-Soso/Lenard J. Cohen, eds, State Collapse in Southeastern Europe, West Lafayette/IN 2008; Eric Gordy, Destruction of the Yugoslav Federation. Policy or Confluence of Tactics?, in: Dragović-Soso / Cohen, State Collapse in Southeastern Europe; Nikica Barić, Srpska pobuna u Hrvatskoj 1990-1995, Zagreb 2005; Harry Hayball, Serbia and the Serbian Rebellion in Croatia (1990-1991), Ph.D. Thesis, Goldsmiths, University of London 2015.

${ }^{32}$ Valère Philip Gagnon, The Myth of the Ethnic War, Ithaca/NY 2004; Mile Bjelajac/ Ozren Žunec, The War in Croatia 1991-1995, in: Charles Ingrao/Thomas Emmert, eds, Confronting the Yugoslav Controversies. A Scholar's Initiative, West Lafayette/IN 2009; Marie-Janine Calic, Ethnic Cleansing and War Crimes 1991-1995, in: Ingrao / Emmert, eds, Confronting the Yugoslav Controversies.

${ }^{33}$ Xavier Bougarel, Bosnie, anatomie d'un conflit, Paris 1996; Steven L. Burg/Paul S. Shoup, The War in Bosnia-Herzegovina. Ethnic Conflict and International Intervention, London, New York/NY 1999.

${ }^{34}$ Dušan Bilandžić, Termination and Aftermath of the War in Croatia, in: Branka Magaš / Ivo Žanić, eds, The War in Croatia and Bosnia-Herzegovina, London, Portland/OR 2001, 84-91. 
and corroborated these with a variety of written sources. Scholars experienced severe limitations on their work, to the point of self-censorship, and often emigration. In many cases, scholars also felt the need to take a stand in the face of war.

To begin with, the outbreak of war had a deeply destructive effect on cooperation between Croatian and Serbian scholars, which translated into the termination of a great number of inter-republican academic projects and the abrupt cessation of telephone and postal communication. As a result of UN resolution 757 from May 1992, which imposed international sanctions on Serbia and Montenegro due to their involvement in the war in Bosnia and Herzegovina, ${ }^{35}$ followed a few weeks later by a resolution of the Croatian Ministry of Science in accordance with the international embargo, ${ }^{36}$ the situation continued to worsen. What is more, as many of my Croatian interlocutors suggested, aside from the legal and material obstructions at play, cooperation with Serbian colleagues in many cases became more difficult as a result of divergent understandings of the nature and the causes of the Yugoslav conflict. While many Croatian researchers saw the conflict as external aggression against Croatia, many Serbian scholars insisted on the notion that the conflict was in fact a civil war. ${ }^{37}$

Moreover, the Yugoslav breakup and the outbreak of war took a serious toll on the Croatian economy, with an average annual economic drop of more than $10 \%$ and an average inflation of more than $800 \%$ between 1989 and $1993 .{ }^{38}$ The consequences of the Croatian privatization programme, with uneven results favouring small fractions of the political and economic elite and affecting small shareholders, also resulted in the economic decline of the middle strata. ${ }^{39}$ In that context, the financial situation for scholars became difficult. As political scientist Ivan Grdešić has noted:

\footnotetext{
35 The UN Security Resolution 757, 30 May 1992, http://undocs.org/S/RES/757(1992).

${ }^{36}$ Naredba za provođenje Rezolucije broj 757 (1992) Vijeća sigurnosti Ujedinjenih naroda u području znanosti, tehnologije i informatike, Narodne novine. Službeni list Republike Hrvatske, 3 June 1992, https://narodne-novine.nn.hr/clanci/sluzbeni/1992_06_32_799.html.

${ }^{37}$ A similar conflict of interpretations, but this time among antiwar activists, has been described by Vesna Janković in the memories of the 'Antiwar Campaign'. Vesna Janković/ Nikola Mokrović, eds, Antiratna kampanja 1991-2011. Neispričana povijest, Zagreb 2011, 102.

${ }^{38}$ Nebojsa Stojcic, Two Decades of Croatian Transition. A Retrospective Analysis, Southeast European Journal of Economics and Business 7, no. 2 (2012), 63-76.

${ }^{39}$ Lenard Cohen, Embattled Democracy. Postcommunist Croatia in Transition, in: Karen Dawisha / Bruce Parrott, eds, Politics, Power, and the Struggle for Democracy in South-East Europe, Cambridge 1997, 69-121, 90-91.
} 
'The Homeland War had deep consequences on the work of our Faculty [Faculty of Political Sciences at the University of Zagreb, A. C.] and on the development of science. Economic production was cut down, military efforts exhausted state funds, and therefore also the means for scientific research and teaching. Many projects were reduced to their minimum. Sustaining continuous teaching and the basic machinery of research and publishing was a great achievement in times of war. International cooperation was interrupted and Croatian science was de facto under international sanctions. ${ }^{\prime 40}$

Furthermore, in a context of economic crisis and under the siege of the Yugoslav People's Army, the rise of nationalism and authoritarian bents during the presidency of Franjo Tuđman added to the profoundly negative effects on the academic and intellectual worlds. Many of my interviewees underlined the difficult political atmosphere that prevailed at the time, and some of them even claimed to have received menacing anonymous phone calls in response to their public opposition to the government. ${ }^{41}$ Public intellectuals such as philosopher Žarko Puhovski have claimed to have had numerous conflicts as a result of their opposition to the government and taking what was labelled a 'Yugoslav' stance. ${ }^{42}$ Other cases of aggression against critical intellectuals have become widely known, such as the attack on the feminist thinkers Slavenka Drakulić, Rada Iveković, Vesna Kesić, Dubravka Ugrešić, and Jelena Lovrić on the pages of the weekly Globus, after which some of them decided to leave the country for fear of further assaults. ${ }^{43}$ Their decision to emigrate was shared by many intellectuals and young scholars, thus deepening a serious brain drain that in fact had begun long before the war, during the previous, state socialist, decades. ${ }^{44}$ In some cases, political pressure was exercised inside universities and research institutes. According to some of the testimonies, professors at the Faculty of Political Science of Zagreb University, for instance, were frequently attacked or side lined, when they were associated with the communist regime or with the successor to the Communist Party, the Party of Democratic Reform (Stranka demokratskih promjena, SDP). This was

\footnotetext{
${ }^{40}$ Ivan Grdešić, Razvoj političke znanosti i demokratska tranzicija u Hrvatskoj, in: Mirjana Kasapović, ed, Izlazak iz množine? Stanje hrvatske političke znanosti, Zagreb 2007, 121-135, 129.

${ }^{41}$ Sociologist 1, personal interview, Zagreb, February 2017; Sociologist 2, personal interview, Zagreb, February 2017.

42 Damir Pilić, Marx nije mrtav, Zagreb 2016, 81-86.

${ }^{43}$ Hrvatske feministice siluju Hrvatsku!, Globus, 11 December 1992; Chiara Bonfiglioli, 'Bourgeoises' puis 'traîtres à la nation'. Dissidences féministes vis-à-vis du pouvoir étatique, avant et après la partition de la Fédération yougoslave, Tumultes 32-33, no. 1-2 (2009), 170-194.

${ }^{44}$ Branka Golub, Croatian Scientists' Drain and Its Roots, International Migration 34, no. 3 (1996), 609-625, DOI: 10.1111/j.1468-2435.1996.tb00547.x; Mirjana Morokvasic, La mobilité des élites scientifiques de l'Autre Europe: exode ou circulation?, Revue d'études comparatives EstOuest 27, no. 3 (1996), 31-73.
} 
the case of Jovan Mirić, incidentally a Serb, who saw himself financially and politically cornered and eventually decided to take early retirement. ${ }^{45} \mathrm{~A}$ more blatant case can be found in the financial strangulation performed on certain research institutes, as in the case of the Institute for Social Research at Zagreb University (Institut za društvena istraživanja Sveučilišta u Zagrebu, IDIS), one of the most active and renowned sociological institutions in Yugoslavia since its establishment in $1964 .^{46}$

These attacks must be considered also in the context of another, subtler, strategy of the government to intrude in the world of social sciences, which Dolenec, Doolan, and Žitko have labelled as 'institutional parallelism': the establishment of new and rival institutions, such as the discipline of Croatian Studies (Hrvatski studiji) at the University of Zagreb and the Institute for Applied Social Sciences (Institut za primijenjena društvena istraživanja), later rebaptized Institute for Social Sciences 'Ivo Pilar'. The latter offered study programmes and developed research agendas that were more in line with the rising national sentiment that prevailed at the time. As Dolenec, Doolan and Žitko have shown, these new institutions allowed for many a researcher to make significant progress in their career through theoretical adaptation or ideological conversion to the new values that the HDZ government aimed to promote in academia. ${ }^{47}$

According to my interlocutors, although in practice these new institutions often embraced researchers of diverse ideological orientations, many social scientists experienced them as 'too right-wing oriented', ${ }^{\prime}$ as an 'HDZ institute', ${ }^{49}$ or simply as part of a wider strategy by the government 'to weaken the red Faculty [the Faculty of Arts, A. C.] ${ }^{50}$ In some cases, these perceptions were founded on open declarations by institutional representatives. As one of my interviewees, at that time a young sociologist working at the Faculty of Arts at the University of Zagreb, remembered from a conversation with the then

\footnotetext{
${ }^{45}$ Political Scientist 1, personal interview, Zagreb, April 2016; Political Scientist 2, personal interview, Zagreb, April 2016; Political Scientist 3, personal interview, Zagreb, February 2017. Among other things, Jovan Mirić was well known for his role in the Yugoslav constitutional debates of the 1980s, cf. Jovan Mirić, Sistem i kriza. Prilog kritičkoj analizi ustavnog i političkog sistema Jugoslavije, Zagreb 1985.

${ }^{46}$ Petak, Osnivanje i razvoj Instituta za društvena istraživanja Sveučilišta u Zagrebu; Agustín Cosovschi, Sociologija u tranziciji, in: Petar Bagarić / Orlanda Obad, eds, Devedesete. Kratki rezovi, Zagreb (forthcoming).

${ }^{47}$ Danijela Dolenec/Karin Doolan / Mislav Žitko, Plus ça change. Mapping Conversions in the Croatian Academic Field in the Early 1990s, in: Florian Bieber / Harald Heppner, eds, Universities and Elite Formation in Central, Eastern, and South Eastern Europe, Zurich 2015, 243-266.

${ }^{48}$ Sociologist 3, personal interview, Zagreb, February 2017.

49 Sociologist 4, personal interview, Zagreb, April 2016.

${ }^{50}$ Philosopher-Sociologist 1, personal interview, Zagreb, February 2017.
} 
director of the Institute for Social Sciences 'Ivo Pilar': 'The idea was clear: we have the left-wing IDIS, so we need to have a counterbalance. ${ }^{51}$

\section{Taking a Stand in the Context of War}

The government's authoritarian bent and the recurrent harassment of critical intellectuals were to a great extent eased by the rise of a general atmosphere of national defence that resulted from the context of war. ${ }^{52}$ The JNA's invasion of Croatia was perceived by many as an existential threat, thus reinforcing national solidarity regardless of ideological orientations. As Srdan Dvornik has claimed:

'Practically for the whole population (leaving aside, of course, those in rebel regions under Serbian control) the war in Croatia was an attack against their country, that posed an existential threat to many and a symbolic threat to all. Even those who did not support Tuđman or his party considered that it was no time for public criticism and even less for civil disobedience, not even a symbolic one. ${ }^{53}$

Even though in Zagreb, the main centre of Croatian intellectual and scientific life, the real likelihood of violence was minor, during 1991 and 1992 its 900,000 inhabitants lived in fear of a potential attack, which eventually came to be fifty kilometres away from the capital. People had to cope with an atmosphere of widespread paranoia, with frequent reports of snipers and 'fifth columnists. ${ }^{54}$ As stated by one interviewee, then actively engaged in antiwar activism and critical of the Tuđman administration:

'I think one can legitimately say this was not a civil war: this was an invasion, Croatia was threatened. Ok, it did not help how they treated the Serbs; it did not help that Tuđman was as nationalist as he was, but there was a sense in which you know there was a need to defend the homeland. ${ }^{55}$

While many researchers and intellectuals would respond to war by joining pacifist groups such as the 'Antiwar Campaign' (Antiratna kampanja), ${ }^{56}$ others would take on the defence of their country on military ground, joining the Croatian armed forces, at times of their own will. ${ }^{57}$ Personal choices and ideological orientation notwithstanding, the reality of war in Croatia drove many

\footnotetext{
51 Sociologist 5, personal interview, Zagreb, February 2017.

${ }^{52}$ Cohen, Embattled Democracy. Postcommunist Croatia in Transition, 84; Gagnon, The Myth of the Ethnic War, 94, 146.

${ }_{53}$ Srđan Dvornik, Akteri bez društva, Uloga civilnih aktera u postkomunističkim promjenama, Zagreb 2009, 206.

${ }^{54}$ Laura Silber / Allan Little, Yugoslavia. Death of a Nation, New York/NY 1996, 196.

55 Sociologist 6, personal interview, Zagreb, March, 2016.

56 Bojan Bilić, We Were Grasping for Air, Baden-Baden 2012.

57 Philosopher-Sociologist 1, personal interview, Zagreb, April 2016.
} 


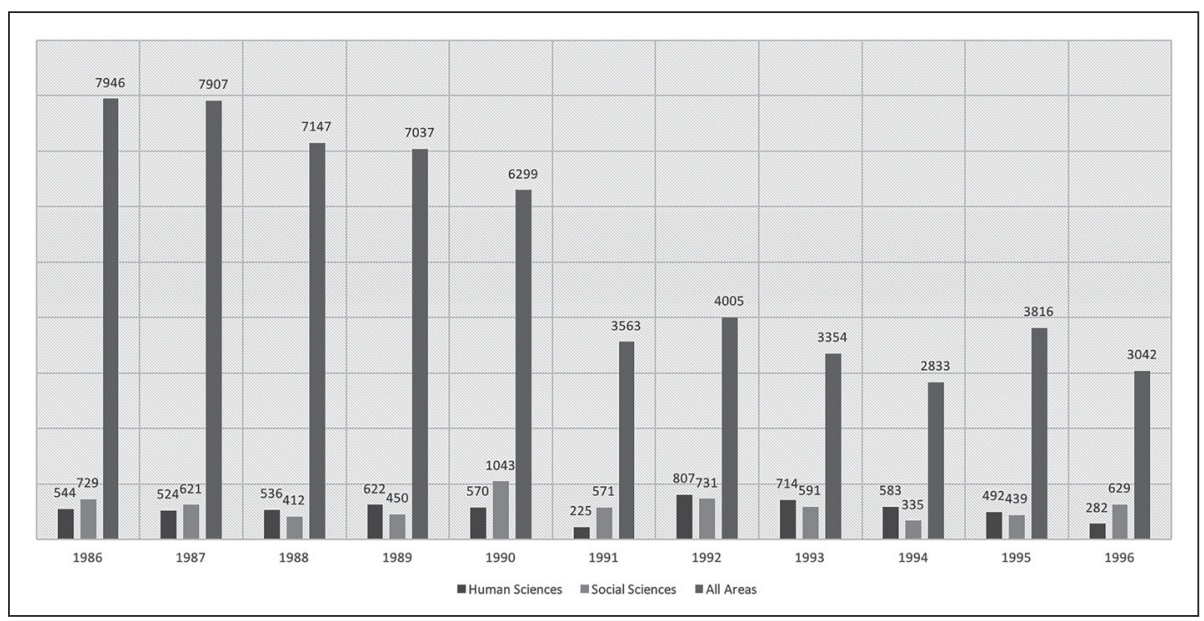

Figure 1: Number of Completed Works (1986-1996). Source: Author's Compilation.

researchers towards deeper political commitment, making them reflect on their own position in such a context:

'We asked ourselves what our perspective was. Here we only watched a heavy ideologized TV, bombs were falling ... And now, from this partial dimension, [we asked ourselves,] where is my voice in all of this? ${ }^{\prime 58}$

Although all these developments left deep traces on the memory and the work of researchers, as well as particularly harmful effects on certain institutions, statistics from the time indicate that the production of social and human sciences did not suffer quantitatively. Whereas the whole of the Croatian scientific system suffered a significant crisis during the time, with a drop of more than $60 \%$ in its total output, social and human sciences remained more stable (see Figure 1). Judging by the data gathered, this resistance could be interpreted as the result of the relatively low financial necessities of social sciences, the replacement of certain institutions for others, and more generally thanks to social scientists' adaptability to shift towards theoretical work in times of crisis. What is more, a look at the specific output of social and human sciences during the period 1986-1996 (see Figure 2) is also revealing: the early 1990s show some significant peaks, which seems to indicate that the Yugoslav crisis and the beginning of the conflict may have even invigorated reflection and production, at least in some disciplines.

${ }^{58}$ Ethnologist 1, personal interview, Zagreb, March 2016. 


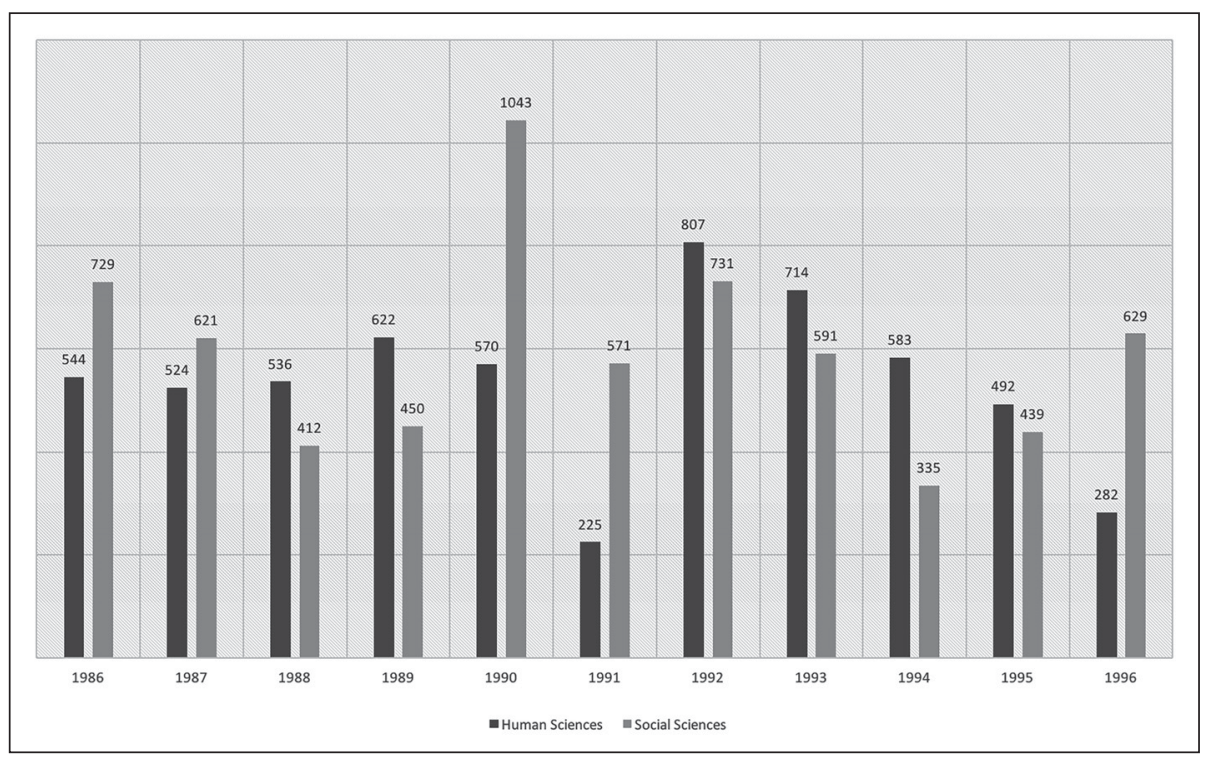

Figure 2: Number of Completed Works in the Human and Social Sciences (1986-1996). Source: Author's Compilation.

Regardless of possible explanations of these statistical series, in fact despite the outbreak of violence, social meltdown, economic collapse, and ideological pressures, the early 1990s were a time in which many Croatian social scientists managed in one way or another to save their voices, keep writing, and take a stand in the face of a novel and pressing context.

As far as ethnologists, here at stake, were concerned, how did they make use of their voices in this time of turmoil? How did they respond to the outbreak of war? And more generally, how did this context impact on the ongoing transformation that Croatian ethnology had undertaken since the 1970s, when it started to turn from a traditional and scholastic pursuit to a modern discipline concerned with the problems of contemporary society?

\section{Croatian Ethnology and the Politics of Engagement}

As elaborated above, the outbreak of war found Croatian ethnology in the midst of a deep process of theoretical and political change, with a strong centre at the Institute for Ethnology and Folklore Research in Zagreb. By the end of the 1980s, there was a general perception of political and social irrelevance, as it had been fostered during state socialism. Criticism of this situation was on the rise, and the turbulent context of the early 1990s would provide 
scholars with yet another reason to engage politically through their word. Dunja Rihtman-Auguštin would openly encourage ethnologists to politicize. In 1992, in an article titled 'Ethnology. After Socialism', she continued some of Lydia Sklevicky's ideas by asking what the role of ethnology should be in the face of war, and after decades of political silence:

'In face of killing, destruction and hate, ethnology has found itself, probably like many other disciplines in the humanities, confronting the key question of its own purport: can it continue on its scholarly path [...]? In times like the current ones, should it inquire into the depths of mentalities, not only as far as human conduct is concerned, but human values? Can the analysis and the interpretation of symbols uncover something essential, that other sciences do not see? Can these even start approaching everyday (war) life if they do not first explain its immediate past? [...] As ethnologists we have frequently done fieldwork interested exclusively in the 'objects' of our profession; we have avoided that part of human relations and culture that is infected by politics; we have ignored these, among other things-not only the partisan tales about the war, we were far from even sensing the trenches and their victims. [...] I cannot therefore but start with a critique of ethnological practices. The questioning of basic assumptions, which has characterized ethnology during the last decades, needs to once again mark a new beginning. The ethnology of postsocialism needs to start from such questioning and such critique. ${ }^{59}$

Rihtman-Auguštin questioned what she considered to be a long political silence on the part of Croatian ethnologists during the socialist period, as a result of either political pressure or self-censorship. She encouraged them to address hitherto silenced subjects, such as the destruction of tradition, the national traits of traditional cultures, and the de-Christianization of popular culture, thereby taking a stand against their marginalization. Her conclusion was similar to what Lydia Sklevicky had noted-ethnology was to take a new position vis-à-vis the current political processes:

'Under the pressure of the everyday of war, we cannot conceive of ethnology only as a science of the people, or as the science of cultural processes in small entities inside a wider system [...]. We need to think about ethnology inside the realm of politics, and we will find ourselves in a millstone, being ground and unable to escape. ${ }^{60}$

From the 1990s, the anthropologized Croatian ethnology as it was practised at the IEF would break with its tradition of political neutrality. From then on, the political would become an inevitable dimension of analysis. As one ethnologist who belongs to the generation that joined the IEF in the late 1980s put it, "precisely the time which otherwise was declared as "post-ideological"

${ }^{59}$ Dunja Rihtman-Auguštin, Etnologija socijalizma i poslije, Etnološka Tribina 22, no. 15 (1992), 81-89, 82-83.

${ }^{60}$ Rihtman-Auguštin, Etnologija socijalizma i poslije, 87. 
Table 1: Topics in Etnološka Tribina (1991-1995). The topics do not constitute entirely discrete categories. As there is thematic overlap and many articles address more than one issue, these categories are not mutually exclusive. Source: Author's compilation.

\begin{tabular}{|l|c|c|c|c|c|c|}
\hline YEAR & 1991 & 1992 & 1993 & 1994 & 1995 & TOTAL \\
\hline Total number of articles & 14 & 15 & 12 & 11 & 10 & 62 \\
\hline TOPICS & & & & & & \\
\hline $\begin{array}{l}\text { Popular religion and } \\
\text { religious ceremonies }\end{array}$ & 6 & 3 & 4 & 4 & 3 & 20 \\
\hline Popular dances and music & 1 & 0 & 0 & 2 & 0 & 3 \\
\hline Economy and production & 1 & 0 & 0 & 0 & 0 & 1 \\
\hline Symbology in folklore & 1 & 0 & 0 & 1 & 0 & 2 \\
\hline Minorities & 2 & 0 & 1 & 0 & 0 & 3 \\
\hline Oral literature & 1 & 0 & 0 & 1 & 0 & 2 \\
\hline Architecture & 1 & 1 & 0 & 0 & 4 & 6 \\
\hline War & 0 & 8 & 1 & 1 & 0 & 10 \\
\hline Methodological issues & 0 & 3 & 1 & 0 & 0 & 4 \\
\hline Socialism & 0 & 1 & 1 & 1 & 0 & 3 \\
\hline Reflections on the ethnos & 0 & 1 & 1 & 1 & 0 & 3 \\
\hline National identities & 0 & 1 & 0 & 1 & 1 & 3 \\
\hline Material culture & 1 & 2 & 3 & 1 & 1 & 8 \\
\hline History of ethnology & 1 & 1 & 3 & 0 & 2 & 7 \\
\hline Varied customs and mores & 1 & 0 & 1 & 2 & 1 & 5 \\
\hline Gender & 0 & 0 & 0 & 1 & 0 & 1 \\
\hline
\end{tabular}

at a global scale, for us meant the beginning of an ideological time in our scholarship'. ${ }^{61}$

The outbreak of war would entail a deeper engagement with what was perceived as the urgent needs of a society under siege. For instance, a look the editions of Etnološka tribina (Ethnological Tribune), the journal of the Croatian Ethnological Society (Hrvatsko etnološko društvo), shows that war became a major research interest: out of 62 articles published between 1991 and 1995, ten focused on the war as such, while many others referred to its context (see Table 1).

To be sure, the 'political turn' of Croatian ethnology cannot be understood without considering the key theoretical transformations that had taken place up to the early 1990s. Among the many factors that contributed to changing the ethnologists' approach were the theoretical influences that had brought

${ }^{61}$ Ethnologist 1, personal interview, Zagreb, April 2016. 
a new language to the discipline, and a new self-definition. Postmodern anthropology, as professed by scholars such as James Clifford and George Marcus, encouraged Croatian ethnologists to re-define their approach. ${ }^{62}$ The ethnologist-anthropologist would, from then on, be conceived as an author who was inevitably conditioned by the context in which she or he worked.

As a result, the act of writing itself would gain a new significance. Following Lévi-Strauss, ${ }^{63}$ writing was traditionally considered to be the elementary phase of anthropological work. Under its new postmodern influence, ethnography became a field of experimentation, sometimes closer to poetry, and resistive to academic formalities. By replacing ideological neutrality for active political engagement, this new approach questioned the very notion of objectivity. Maja Povrzanović, a researcher at the IEF, wrote in 1992:

'In this text, the term "ethnography" means "writing culture", referring to what American cultural anthropology has defined as the act of writing. The literal translation of "writing culture" is the "writing of culture" [pisanje kulture]. This syntagma, essential for the authors of the "new ethnography", rules out the possibility of an objective description or a representation of cultural phenomena guided by an abstract intellectual interest. ${ }^{\prime 64}$

The rejection of 'abstract intellectual interest' as a motivation for research meant a significant break with academic traditions. It was now assumed that it was not the anthropologists' quest for knowledge, but their participation in a wider configuration of power relations, that moved their work and guided their mission in the field.

Thus, Croatian ethnology as was practised at the IEF would enter the 1990s having gone through a series of converging transformations: the collapse of a tradition of political neutrality that had been dominant for much of the $20^{\text {th }}$ century, the arrival of new theoretical paradigms that offered critical tools against that same tradition, and a novel context of political and social crisis that provided a set of conditions in which to try out new ways of practising the discipline. To further illustrate these disciplinary transformations, the last section of this article focuses on one of Croatian ethnology's more eminent, indeed paradigmatic, products of the time: the book Fear, Death, and Resistance. An Ethnography of War. Croatia, 1991-1992, edited by Ines Prica, Lada Čale Feldman, and Reana Senjković in $1993 .^{65}$

${ }^{62}$ James Clifford / George E. Marcus, eds, Writing Culture. The Poetics and Politics of Ethnography, Berkeley/CA 1986.

${ }^{63}$ Claude Lévi-Strauss, Anthropologie structurale, Paris 1958.

${ }^{64}$ Maja Povrzanović, Etnologija rata. Pisanje bez suza?, Etnološka tribina 22, no. 15 (1992), 61-80, 61-62.

${ }^{65}$ Lada Čale Feldman / Ines Prica / Reana Senjković, eds, Fear, Death, and Resistance. An Ethnography of War - Croatia 1991-1992, Zagreb 1993. 


\section{The Ethnography of War}

\section{A Novel Language for Novel Times}

In 1992, the journal Narodna umjetnost issued by the IEF published a thematic issue devoted almost entirely to the war underway in Croatia. The edition comprised 13 articles. The introduction started with a prologue by the editor, Aleksandra Muraj, who defined the initiative as 'an effort to make a contribution to our Motherland in a difficult time of its history'. ${ }^{66}$ Among the articles, a dossier entitled 'Poetics of Resistance' stood out, which included the works of three young doctoral researchers working at the institute, namely Lada Čale Feldman, Reana Senjković, and Ines Prica. This dossier first featured an analysis of political rallies in Croatia during the elections of 1990 and the initiating war. This was followed by a study of the new national and political symbols that flooded Croatian society, in the form of flags, posters, badges, and brooches. The third text analysed everyday life in Croatia in times of war. The dossier was dedicated 'to all those who did not have a chance', thus declaring from the start the authors' ambition to connect their work to the current situation in Croatia. ${ }^{67}$ The issue concluded with a letter in English language that had been sent by the IEF to colleagues all around the world in November 1991. In the letter, they had explained that the conflict in Yugoslavia was the consequence of the ambitions of Serbian nationalism and the Yugoslav army. The authors described the horrors of war, asking for support and attempting to persuade the international academic community that the conflict was not symmetrical and that there was therefore no room for neutrality. ${ }^{68}$

One year later, the dossier 'Poetics of Resistance', together with a number of articles from other journals, would be translated into English and published as a book, Fear, Death and Resistance. An Ethnography or War-Croatia, 1991-1992. It included a final section entirely devoted to life stories of civilian war victims in Croatia. In spite of its somewhat chaotic arrangement, the book would become one of the most cited works of the IEF, a paradigm of the politically engaged ethnology of the 1990s. It started with a brief preface by the three editors, defining their book in deeply emotional and engaged terms:

'The uneasiness which spun around the assumed importance to give a scholarly image to the war, around that necessity to think and speak a language which in wartime is totally useless and senseless [emphasis added], appertains to the fractures in the

\footnotetext{
${ }^{66}$ Riječ urednice, Narodna umjetnost 29, no. 1 (1992), 9.

67 Poetics of Resistance, Narodna umjetnost 29, no. 1 (1992), 45-104.

${ }^{68}$ Apel Instituta za etnologiju i folkloristiku kolegama i srodnim ustanovama u svijetu, Narodna umjetnost 29, no. 1 ( 1992).
} 
image of the future brought about by war. Scholarship relies on a determined sequence of time. On account of those from whom time has been taken away, temporarily or forever, scholarship should ask itself to what-and whose!-future it is pledged. The following studies aspired (each in its own way) to somehow solving the dilemma of "doing scholarly works" in such inhuman and, for many, futureless times. Therefore, the motive for writing was both academic (in the sense of producing scholarly results, or suggesting a scholarly image of war) and also, if not more so, a matter of the authors' decision to speak up.'69

The introduction illustrates the general tone of the book, characterized by a general questioning of scholarly authority and by the persistence of the authors' voices. These common traits notwithstanding, there were significant stylistic and thematic differences and variations among the contributions, as a more detailed examination of several of them illustrates.

Lada Čale Feldman, who had recently graduated from the Faculty of Arts in Zagreb, specializing in theatre analysis, focused on a novel phenomenon in postcommunist Croatia: mass political rituals, in particular electoral rallies, military parades, and protests against the war. ${ }^{70}$ Analysing the symbolic construction of these rituals from the perspective of performance, that is, dealing especially with their extra-discursive dimension, she showed how each political force had constructed a different image of the future in face of the Croatian elections in 1991. In her analysis, Čale Feldman critically scrutinized the messages transmitted by the ruling elites. Her critical distance, nevertheless, was significantly weaker in her analysis of civil demonstrations. Aiming to reproduce how citizens' organizations denounced and condemned war, she often merged her own voice with the voice of the organizations she explored. One of these was 'Mothers for Peace' (Bedem ljubavi), a non-governmental movement of mothers of men who had been mobilized by the Yugoslav People's Army, in spite of Croatia having already begun its path towards independence. During the 1990s, this NGO would enunciate a strongly nationalist and conservative discourse. ${ }^{71}$

Ines Prica's chapter, entitled 'Notes on Ordinary Life in War' proved especially interesting. She wished to draw from 'a less authoritative discourse', 'one that does not incline to definite conclusions and which is nearer to the effort of

\footnotetext{
${ }^{69}$ Čale Feldman / Prica / Senjković, eds, Fear, Death, and Resistance, 2.

${ }^{70}$ Lada Čale Feldman, The Theatralisation of Reality. Political Rituals, in: Čale Feldman / Prica / Senjković, eds, Fear, Death, and Resistance, 5-23.

${ }_{71}$ Ana Miškovska Kajevska, Feminist Activism at War. Belgrade and Zagreb Feminists in the 1990s, New York/NY 2017.
} 
documentation and producing of materials'. ${ }^{72}$ She examined several problems connected to life in war, such as the possibility and meaning of writing about war, the construction of the image of the Serbian enemy in the discourse and the imagination of contemporary Croatian society, and the everyday experiences of people displaced by military aggression. The most captivating feature of the article was its experimental character. Not only did Prica display almost as much text in the footnotes as in the body text, she also employed a puzzling, eminently poetic and impressionist style. ${ }^{73}$

Maja Povrzanović, in her chapter, focuses on fear. On the basis of a survey on the printed press, radio, and TV programmes, of conversations with victims of the war, and her own personal experience, she embarked on an anthropological analysis of emotions, aiming to reconstruct the role that fear had as a driving force behind hitherto rather unknown forms of behaviour in Croatian society. Her chapter is of a moving and shocking quality, offering a detailed analysis of the everyday life of the civil population in Croatia during the incursion of the Yugoslav army, a critique of how intolerance and xenophobia were produced through the massive spread of fear through the media and through the manipulative spreading of rumours. Here, too, the author's personal political engagement is quite obvious: Povrzanović recurs to a first-person narrative: personal reflection, reference to rumours and stories transmitted by friends and acquaintances, as well as the repeated use of pronouns such as 'we' or 'us', propelled the author frequently to centre stage, as part and parcel of those she explored.

As these examples show, Fear, Death, and Resistance provided the reader with a thought-provoking exercise. Moreover, it endeavoured to shed light on the anthropologists' contradictions and dilemmas when positioning themselves in face of a violent and politically radicalized context.

\section{The Book and Its Meaning}

Fear, Death, and Resistance caused mixed responses. While it was generally well received by many in the Croatian political, intellectual, and academic scene, it did trigger significant criticism. Two elements stood at the centre of that criticism: on the one hand, what was perceived as a non-scholarly tone, and in particular the scepticism the authors put forth regarding objectivity, denying that it was possible to adopt an unbiased position in anthropological work. On the other hand, the political implications of the book were criticized, as its self-victimizing tone was considered to be in line with the mounting

\footnotetext{
${ }^{72}$ Ines Prica, Notes on Ordinary Life in War, in: Čale Feldman / Prica / Senjković, eds, Fear, Death, and Resistance, 44-71, 44.

${ }^{73}$ Prica, Notes on Ordinary Life in War.
} 
nationalism in Croatia. ${ }^{74}$ The Serbian anthropologist Slobodan Naumović criticized the ethnography of war particularly convincingly, on the grounds that a lack of critical distance could be useful for nationalist policies:

'Because of their uncompromising advocacy approach, radically subjective position, and militant tone, and because of establishing a sentimental identification between the suffering-and-crying researcher and the suffering-and-crying objects of study, some among the trendy and usually well written pieces of Croatian anthropology of the Own-as-object-of-aggression, apart from their obvious quality as ethnographies of a collective state of fear, remained more or less reflective self-portraits of ethnologists as constructors of the rhetoric of national victimisation. ${ }^{75}$

Naumović's criticism is strong. It triggered the response of Ines Prica, one of the editors of the volume, some years later, in an attempt to relocate the ethnography of war in the unsettled context of the 1990s. She questioned Naumović's rational ideal of 'pure' scholarship and underlined how ethnologists in the formerly Yugoslav region opposed national mythification, questioned national stereotypization, and took a clear stance in face of ethnicized theoretization. ${ }^{76}$ The disagreement between the two scholars is revealing, indicating the growing gap between the worldviews of scholars in Serbia and Croatia in the course of the 1990s. However, in order to critically appraise the book at stake here, a discussion beyond individual assessments is necessary.

The general subjectivism that characterized Fear, Death, and Resistance needs to be understood in the wider intellectual context in which the debate on the relation between politics and scholarship took place. For instance, in June 1995 the Chicago-based journal Current Anthropology launched a dossier entitled 'Objectivity and Militancy. A Debate', with contributions by authors such as the cofounder of cognitive anthropology, Roy D'Andrade, Nancy Scheper-Hughes, known for coining concepts such as 'militant anthropology' and 'anthropology "with its feet on the ground"', the founder of the anthropology of the contemporary, Foucauldian Paul Rabinow, and cultural materialist Marvin Harris. ${ }^{77}$ The radically subjective approach put forward by the Croatian ethnologists at the time thus was part of a global trend in

\footnotetext{
${ }^{74}$ Naumović, Identity Creator in Identity Crisis; Ina-Maria Greverus, Poetics within Politics. Towards an Anthropology of the Own, Anthropological Journal of European Cultures 8, no. 2 (1999), 7-26, 23, https://www.jstor.org/stable/43234855; Čapo/Gulin Zrnić, Un siècle d'ethnologie croate, 194.

${ }_{75}$ Naumović, Identity Creator in Identity Crisis, 93.

${ }^{76}$ Ines Prica, Autori, zastupnici, presuditelji. Hrvatska etnologija u paralelizmima postsocijalističkog konteksta, in: Ljiljana Gavrilović, ed, Zbornik radova Etnografskog instituta SANU 21, Belgrade 2005, 29-44.

77 Current Anthropology 36, no. 3 (1995).
} 
anthropology, of a wider discussion that went far beyond the singularities of the Croatian context.

A second but related issue concerns the controversy around the war context and the meaning of political positioning. Judging by the testimonies gathered for this study, not all critics interpreted the book as in line with Croatian national interests. For instance, according to one of the interviewees, the book was received in a generally positive manner by the academic world. What is more, Zorica Vitez, director of the Institute for Ethnology and Folklore Research between 1986 and 1999-married to theatre and film actor Zlatko Vitez, minister of culture in the HDZ-led government in 1994/95-is reported to have considered the book to be 'not enough sympathetic' to Croatia in the context of the war. ${ }^{78}$ Similar, if not stronger, reactions, on contrary grounds, namely rejection, came from international academics and journalists, who interpreted the book as a defence of Croatia and a useful piece for the Tuđman administration. The latter's international image was affected not least by the HDZ's repeated flirting with Ustasha symbols and insistence on rehabilitating Croatian nationalism, which included downplaying the violence committed against Serbs and others during the Second World War. ${ }^{79}$ Given that the book exclusively focused on the violence afflicted on Croatians during the Yugoslav breakup, some observers considered it to be functional to the Tuđman administration, which attempted to win over international approval by exploiting Croatia's condition as a target of aggression. For example, one of the contributors to the book told how she was accused of defending a fascist government when doing a radio interview for Radio 'France Culture' in Paris in 1992 to promote the publication. ${ }^{80}$ Another author similarly claimed to have had clashes with international colleagues on the same grounds. ${ }^{81}$

Two aspects in particular may help to assess to what extent Fear, Death, and Resistance partook in constructing the nationalist narrative of those years. Most importantly, contrary to what many of the international commentators back then said about the conflict in the former Yugoslavia, the book adopted a clearly constructivist perspective on ethnicity. This means that its authors drew from the developments in Croatian ethnology that had long ago deconstructed essentialist notions of the ethnos. They strove to show that the events in Croatia were not the result of an 'inevitable' clash between mutually excluding national cultures, but rather of conflicting political strategies.

\footnotetext{
78 Ethnologist 2, personal interview, Zagreb, February 2017.

${ }^{79}$ Bette Denitch, Dismembering Yugoslavia. Nationalist Ideologies and the Symbolic Revival of Genocide, American Ethnologist 21, no. 2 (1994), 367-390, DOI: 10.1525/ae.1994.21.2. $02 \mathrm{a} 00080$.

${ }^{80}$ Ethnologist 3, personal interview, Zagreb, February 2017.

81 Ethnologist 1, personal interview, Zagreb, April 2016.
} 
Second, however, in spite of the book's theoretically refined analyses, its reception and promotion seem to indeed have been engulfed in the contemporaneous nationalist contexts in which it was produced. A video from the book's presentation in 1993 at the Museum of Samobor in Croatia is revealing in this regard. The film shows the then editor of Narodna umjetnost, Aleksandra Muraj, presenting the book as 'a contribution to the Motherland'. The volume's three young editors sit at a table on which a plethora of folkloristic and religious objects of all kinds are displayed, from vases to paintings with traditional Christian symbols. Next to them sits folklore singer Dunja Knebl, who had just started her career back then and concluded the book presentation with songs from the Croatian region Medjimurje. ${ }^{82}$

The setting up of this scene, heavily marked as it was by symbols of Croatian nationhood, is telling in that it reveals how Fear, Death, and Resistance was contextualized at the time. Much as the book was critical of the aggressive nationalist policies of the time and, even though it certainly made a powerful impact on the field of Croatian ethnology by virtue of its stylistic and theoretical qualities, it succumbed, via a nationally framed approach and an occasionally dramatic tone, to the anxieties of the time and was also testimony to how strong was the feeling of national victimhood. Fear, Death, and Resistance thus both had a profound influence on local ethnology and was inextricably linked the wider process of national affirmation that Croatian society went through during the 1990s.

\section{Conclusion. War as a Problem and as a Solution}

Ethnology, as it was practised at the Institute for Ethnology and Folklore Research during the early 1990s, offers an intriguing case of disciplinary transformation in extreme times. Croatian ethnology entered the 1990s stricken by a disciplinary predicament characterized by widespread self-perception of marginality as a result of a long tradition of political neutrality. The Yugoslav breakup and the outbreak of war meant a radical change of circumstances. The violent dissolution of the country posed manifold obstacles to social sciences, obstructing the work of many institutions, and leaving deep marks on scholars. Nevertheless, Croatian social scientists managed to keep up their work and to speak up, with many taking a stand against the actions of the Yugoslav People's Army.

${ }^{82}$ Promocija knjige 'Fear, Death and Resistance' u Samoboru, 28 April 1993, uz sudjelovanje Dunje Knebl s međimurskim pjesmama u gitaru, Video Archive of the Institute for Ethnology and Folklore Research, Zagreb 1993. 
In the case of ethnology, as an example of one of its central institutions, the IEF, shows, that prise de parole was radical. Merging with the growing overall opposition to a long tradition of political silence, and inspired by new theories and methodological approaches to anthropological work, a number of Croatian ethnologists set out to inquire into the realities of war, engaging personally and politically with a society they perceived to be endangered. The war of the 1990s, thus, not only did not hamper the development of Croatian ethnology, but, ironically, helped its regeneration. Young ethnologists seized the opportunity to commit themselves to a victimized society and to participate in a larger cultural and political process of national revival. The Yugoslav crisis provided them with the possibility they had been searching for in order to renovate their discipline.

The transformations of ethnology as practised at the IEF has had longterm implications for Croatian ethnology. In particular, the political engagement triggered by the outbreak of war shows how much ethnology during the 1990s remained linked to transformations in the political domain: after more than a century of its existence, Croatian ethnological research and its impact were still connected in many ways to wider concerns over state building in the Yugoslav space. The controversies over the ethnography of war, as shown in this study, shed a sharp and sudden light on the eminently political nature of ethnological research. Regardless of a scholar's personal motivations and irrespective of their political persuasion, a discipline that is concerned mainly with the construction of identity, as both ethnology and anthropology are, will become entangled for good or bad with the intricacies of state building and national politics, and especially so in a time of crisis.

\section{CORRESPONDING AUTHOR}

Agustín Cosovschi CETOBaC/EHESS, 54 boulevard Raspail, 75006 Paris, France.

E-mail: acosovschi@gmail.com 